\title{
Near-Surface Soil Nutrient Changes over Time under Native Prairie and Managed Agriculture in Arkansas
}

\author{
Kristofor R. Brye, Faith Cordes, Marya McKee \\ Department of Crop, Soil, and Environmental Sciences, University of Arkansas, Fayetteville, USA \\ Email: kbrye@uark.edu, flcordes@uark.edu, marya.mckee@gmail.com
}

How to cite this paper: Brye, K.R., Cordes, F. and McKee, M. (2020) Near-Surface Soil Nutrient Changes over Time under Native Prairie and Managed Agriculture in Arkansas. Natural Resources, 11, 243-256. https://doi.org/10.4236/nr.2020.116015

Received: May 5, 2020

Accepted: May 31, 2020

Published: June 3, 2020

Copyright $\odot 2020$ by author(s) and Scientific Research Publishing Inc. This work is licensed under the Creative Commons Attribution International License (CC BY 4.0).

http://creativecommons.org/licenses/by/4.0/

\section{(c) (i) Open Access}

\begin{abstract}
Landuse change from native prairie to managed agriculture can have substantial impacts on soil nutrient properties. Nutrient release from soil organic matter decomposition is the soil's inherent source of long-term fertility; thus it is imperative to understand the effects of continued landuse over time to avoid mistaking actual soil property changes with simple inter-annual variability from one year to the next. The objective of this study was to evaluate the effects of landuse (i.e. managed agriculture and native prairie) in two contrasting physiographic regions (i.e. the Ozark Highlands region of northwest Arkansas and the Grand Prairie region of east-central Arkansas) on the change in extractable soil nutrients over a 15-yr period from 2001 to 2016. Extractable soil $\mathrm{Ca}, \mathrm{Mg}$, and $\mathrm{Zn}$ increased at least two times more over time $(P<0.05)$ under cultivated agriculture in the Grand Prairie than under native prairie in the Grand Prairie or either landuse in the Ozark Highlands. Averaged across landuse, extractable soil $\mathrm{S}$ increased nine times more over time $(P<0.05)$ in the Ozark Highlands than in the Grand Prairie, while extractable soil $\mathrm{Na}$ and $\mathrm{Mn}$ increased at least six times more over time $(P<0.05)$ in the Grand Prairie than in the Ozark Highlands. Averaged across region, extractable soil Mn increased 2.5 times more over time $(P<$ $0.05)$ under native prairie than under agricultural landuse. Results from this long-term field study clearly demonstrate how landuse and regional soil characteristics can affect near-surface soil nutrient contents, which should be taken into consideration when implementing conservation and/or ecosystem restoration activities.
\end{abstract}

\section{Keywords}

Long-Term Study, Soil Properties, Ozark Highlands, Grand Prairie 


\section{Introduction}

Grasslands are one of the most abundant terrestrial ecosystems on Earth, and the most abundant ecosystem in North America [1]. The grasslands of the Great Plains region of North America once extended from Canada to the United States-Mexico border and from the base of the Rocky Mountains to Wisconsin. Specifically, tallgrass prairies were one of the main North American grassland ecosystems, where tallgrass prairies were dominant in the eastern third of the Great Plains [1]. Naturally dense grasslands are widely biologically diverse in flora and macro- and micro-organisms and provide an array of ecosystem functions, such as animal habitat, resource production, soil and water conservation, recreation, and nutrient cycling [2]. Tallgrass prairies are often dominated by $\mathrm{C} 4$ grasses, such as big bluestem (Andropogon geradii), switchgrass (Panicum virgatum), and indiangrass (Sorghastrum nutans) [3].

The large and dense accumulation of organic matter associated with the fibrous roots of monocot grass species contributes to soil organic matter (SOM) and the overall stability of grassland soils, which in turn aid in the reduction of erosion and the regulation of soil water and gas exchange in an environmentally appropriate manner [2]. Grassland root systems affect soil structure through soil penetration as roots grow and proliferate, soil moisture alteration, organic compound exudation, and contribute large quantities of organic matter, carbon (C), and nutrients to the soil through root decomposition [4]. Annual senescence of aboveground vegetation in prairies often allows a thick layer of litter to accumulate on the soil surface that, in the absence of natural fire or a prescribed burn, slowly decomposes to provide another substantial source of organic material and nutrients to eventually be assimilated into the SOM pool and the soil in general. Coupled with soil $\mathrm{pH}$, which affects microbial activity, SOM decomposition, and cation exchange capacity (CEC), the SOM fraction is responsible for the supply and retention of essential plant nutrients, such as $\mathrm{Ca}, \mathrm{Mg}$, and $\mathrm{K}$, and is the source of soil C. However, in regions of the once-prominent and expansive tallgrass prairie, where the climate is relative warm and humid, such as in east-central Arkansas, rapid SOM decomposition associated with landuse change has been shown to impact soil $\mathrm{pH}$ and the long-term storage of soil $\mathrm{C}$ and $\mathrm{N}$ [5], but can also negatively affect the long-term storage of other essential plant nutrients. Brye and Moreno [6] concluded that the resilience of the soil of a native tallgrass prairie is governed by time, where soil biological activity alteration may occur relatively quickly, while soil physical and chemical property changes occur much more slowly.

Brye et al. [7] evaluated soil quality and the relationships among selected soil properties across a climosequence of tallgrass prairies on loamy-textured soils in Arkansas. Results showed that soil quality differed between physiographic regions/climates (i.e. the cooler and drier Ozark Highlands region of northwest Arkansas and the warmer and wetter Grand Prairie region of east-central Arkansas) [7]. Soil organic matter, C, and extractable soil nutrients were generally 
greater the in warmer and wetter climate of Grand Prairie region of east-central Arkansas compared to the cooler and drier Ozark Highlands region of northwest Arkansas. In addition, the relationship between soil properties [i.e. extractable soil nutrients, electrical conductivity (EC), and C:N ratio] also differed in the top $10 \mathrm{~cm}$ of soil between region-climate combinations, where extractable soil $\mathrm{K}$, $\mathrm{Mg}, \mathrm{Na}, \mathrm{S}, \mathrm{Mn}$, and $\mathrm{Cu}$ contents were greater in the Grand Prairie region compared to in the Ozark Highlands [7].

The generally $\mathrm{C}$ - and nutrient-rich soils of grasslands make native prairies susceptible to disturbance by conversion to agricultural landuse. Mechanized agriculture, such as tillage, and common agricultural inputs, such as fertilizers and irrigation water, have the ability to alter soil quality. Many tillage practices, which are severe soil disturbances, homogenize soil particle sizes and increases the likelihood of wind or water erosion by removing the residue cover on the soil surface. Tillage also exposes organic material and SOM to air, where oxidation stimulates SOM decomposition and release of $\mathrm{C}$ as carbon dioxide $\left(\mathrm{CO}_{2}\right)$ to the atmosphere. Brye and Pirani [8] also assessed soil properties in the Grand Prairie region of east-central Arkansas to evaluate the effects of native tallgrass prairie and adjacent cultivated agricultural landuse on near-surface soil-quality-related parameters. Results indicated that SOM, total C (TC), and total nitrogen (TN) were lower and soil $\mathrm{pH}, \mathrm{EC}$, and extractable soil $\mathrm{P}, \mathrm{K}, \mathrm{Ca}, \mathrm{Mg}$, and $\mathrm{Fe}$ were greater under tilled agriculture than native prairie landuse [8].

Brye and West [9] characterized the effects of conversion from native prairie to agricultural grassland management on soil surface properties in the Ozark Highlands and deduced that soil surface properties in agriculturally managed grasslands were similar to those in nearby native prairies. The conversion from native prairie to grazed and ungrazed forage landuse increased soil $\mathrm{pH}$ and extractable soil $\mathrm{P}, \mathrm{Mg}$, and $\mathrm{Mn}$ in the foragelands compared to adjacent native prairies [9]. In contrast, extractable soil $\mathrm{S}$ was greater in the native prairie than in the forageland, while soil EC, extractable soil $\mathrm{K}, \mathrm{Ca}, \mathrm{Na}, \mathrm{Fe}, \mathrm{Zn}$, and $\mathrm{Cu}$, and TN, TC, SOM, and C:N ratio were unaffected from native prairie conversion to forage landuse [9]. The removal of vegetation by haying, as examined by Brye and Moreno [6] in east-central Arkansas, can also affect soil quality in many ways. The long-term productivity of a grassland ecosystem is affected by the duration of annual surface vegetation removal, whether live or dead, and impacts the near-surface soil $\mathrm{C}$ balance and nutrient cycling [6].

More recently, McKee et al. [5] evaluated the effects of landuse (i.e. native tallgrass prairie and managed agriculture) and physiographic region (i.e. Ozark Highlands and Grand Prairie) on SOM and soil C and N sequestration over a 15 -yr period from 2001 to 2016, hypothesizing that, in the top $10 \mathrm{~cm}$, soil $\mathrm{C}$ and $\mathrm{N}$ would remain constant to slightly increase in remnant prairies and decrease under agricultural landuse. Results showed a loss of $4.7 \mathrm{Mg} \cdot \mathrm{ha}^{-1} \cdot \mathrm{yr}^{-1}$ from the native prairie soil during the 15 -yr period between samplings; however, the native prairie actually had 2.5 times greater soil $\mathrm{C}$ compared to the managed agri- 
cultural landuse at the end of the evaluation period in 2016 [5]. Soil organic matter was also 2.5 times greater in all prairie sites sampled in 2016 in both physiographic regions compared to under managed agriculture in Grand Prairie [5]. In addition, soil $\mathrm{pH}$ under managed agriculture was greater $(\mathrm{pH}=6.7)$ than under native prairie $(\mathrm{pH}=4.7)$ in the Grand Prairie [5].

Based on the landuse effects on the change in soil $\mathrm{pH}, \mathrm{SOM}, \mathrm{C}$, and $\mathrm{N}$ over time, as reported in McKee et al. [5], it is likely that plant macro- and micronutrients were negatively affected as well. Given that the release of nutrients from SOM oxidation is the soil's inherent source of long-term fertility, hence sustainability, it is imperative to understand the effects of landuse change over sufficient time so as to not mistake apparent soil chemical property changes with simple inter-annual variability from one year to the next. Therefore, the objective of this study was to evaluate the effects of landuse (i.e. managed agriculture and native prairie) in two contrasting physiographic regions (i.e. the residual-soil-dominated Ozark Highlands region of northwest Arkansas and the loessial- and alluvial-soil-dominated Grand Prairie region of east-central Arkansas) on the change in extractable soil nutrients over a 15-yr period from 2001 to 2016. It was hypothesized that pastureland and managed agricultural landuse will have greater extractable soil nutrient contents compared to native prairie landuse due to management practices and inputs. It was also hypothesized that landuse and region combined will have a more significant impact on soil nutrients compared to region and landuse alone.

\section{Materials and Methods}

\subsection{Regional Characteristics}

The Ozark Highlands $\left(36^{\circ} \mathrm{N}-38^{\circ} \mathrm{N}\right.$ lat., $91^{\circ} \mathrm{W}-95^{\circ} \mathrm{W}$ long.), major land resource area (MLRA) 116A, is located within southern Missouri, northeastern Oklahoma, and 23\% of the MLRA is located within north-central Arkansas [10]. As a whole, MLRA 116A is approximately 2.1 million ha [10], where $93 \%$ of the land is privately owned, with $32 \%$ consisting of grassland [11]. The landscape of the Ozark Highlands, which is part of the Springfield Plateau, is variable. Steep, forested slopes descend into stony valleys and historic prairies and sedimentary rocks dominate, but dolostone, sandstone, limestone, and shale also comprise much of the underlying bedrock in the region [10]. Oak (Quercus spp.), hickory (Carya spp.), and shortleaf pine (Pinus echinata) make up the major tree species, while fescue (Lolium arundinaceum), an introduced species, now dominates many of the managed grasslands [10] [12]. Soils in MLRA 116A are typically weathered from limestone and/or a medium- to fine-textured cherty residuum, typically resulting in shallow to deep Udults and Udalfs [12].

The Grand Prairie $\left(34^{\circ} 0^{\prime} \mathrm{N}-35^{\circ} 30^{\prime} \mathrm{N}\right.$ lat., $91^{\circ} 15^{\prime} \mathrm{W}-90^{\circ} 10^{\prime} \mathrm{W}$ long.) is located within MLRA 134, the Southern Mississippi Valley Loess [10]. Parts of Mississippi, Tennessee, Louisiana, Kentucky, Illinois, Missouri, and 11\% of Arkansas are located within MLRA 134, which occupies about 6.9 million ha [10]. The 
Grand Prairie was once a much larger native tallgrass prairie spanning $~ 130,000$ ha, but has subsequently been reduced to $<1 \%$ of the original land area due to extensive conversion to row-crop production in the region [13]. The Grand Prairie is part of the Mississippi Alluvial Plain, where typically deep Udalfs are present [10] [12]. Hardwood vegetation, such as loblolly pine (Pinus taeda), shortleaf pine, cherry bark oak (Quercus pagodifolia), southern magnolia (Magnoila grandiflora), and cottonwood (Populus deltoides), is also native to and widely distributed in the Grand Prairie and throughout MLRA 134 in general [12].

The climate within both regions is humid temperate. The Grand Prairie is generally warmer than the Ozark Highlands, with mean annual air temperatures of $16.6^{\circ} \mathrm{C}$ and $14.5^{\circ} \mathrm{C}$, respectively [14]. Similarly, the Grand Prairie is generally wetter than the Ozark Highlands, with mean annual precipitation of 126 and 116 $\mathrm{cm}$, respectively [14].

\subsection{Site Descriptions}

Chesney and Stump Prairies (Table 1; Figure 1) are located in the Ozark Highlands region of Benton County, Arkansas, which are fragmented remnants of the historic Lindsley Prairie. In northwest Arkansas, the Lindsley Prairie once extended across more than 4000 ha [15]. The Chesney prairie specifically supports over 450 plant species, 29 of which are native and 18 plant species are recognized as rare [15]. Big bluestem, little bluestem (Schizachyrium scoparium), Indiangrass, switchgrass, large flower tickseed (Coreopsis grandiflora), prairie grayfeather (Liatris pycnosachya), and rattlesnake master (Eryngium yuccifloium) are some of the typical species present in the Chesney Prairie [16]. Sager Creek, an ephemeral stream, divides the Chesney Prairie and many prairie mounds are also present [17]. The soil of the Chesney and Stump Prairies has a loamy texture covering cherty limestone, allowing for moderately to well-drained conditions and moderate permeability [18]. Jay silt loam (fine-silty, mixed, active, thermic

Table 1. Summary of physiographic characteristics by geographic region and history of landuse.

\begin{tabular}{|c|c|c|c|c|c|c|}
\hline $\begin{array}{c}\text { Region/ } \\
\text { Parent Material }\end{array}$ & Site & Landuse & Years Managed & Soil Series & $\begin{array}{l}\text { Soil Taxonomic } \\
\text { Description }\end{array}$ & Slope (\%) \\
\hline \multirow{5}{*}{$\begin{array}{l}\text { Ozark Highlands/ } \\
\text { Residuum }\end{array}$} & \multirow[t]{3}{*}{ Stump Prairie } & Periodically cultivated hayland & $>20$ & Jay & Oxyaquic Fragiudalf & 0 \\
\hline & & Never cultivated, managed pasture & $>20$ & Jay & Oxyaquic Fragiudalf & 0 \\
\hline & & Native prairie & 0 & Jay & Oxyaquic Fragiudalf & 1 \\
\hline & \multirow[t]{2}{*}{ Chesney Prairie } & Never cultivated, managed pastureland & $>20$ & Jay & Oxyaquic Fragiudalf & 2 \\
\hline & & Native prairie & 0 & Jay & Oxyaquic Fragiudalf & 2 \\
\hline \multirow{4}{*}{$\begin{array}{c}\text { Grand Prairie/ } \\
\text { Alluvium }\end{array}$} & \multirow{4}{*}{$\begin{array}{c}\text { Seidenstricker } \\
\text { Prairie }\end{array}$} & \multirow[t]{3}{*}{ Cultivated agriculture } & 31 & \multirow[t]{3}{*}{ Dewitt } & \multirow[t]{3}{*}{ Typic Albaqualf } & 0 \\
\hline & & & 42 & & & 0 \\
\hline & & & 60 & & & 0 \\
\hline & & Native prairie & 0 & Dewitt & Typic Albaqualf & 0 \\
\hline
\end{tabular}




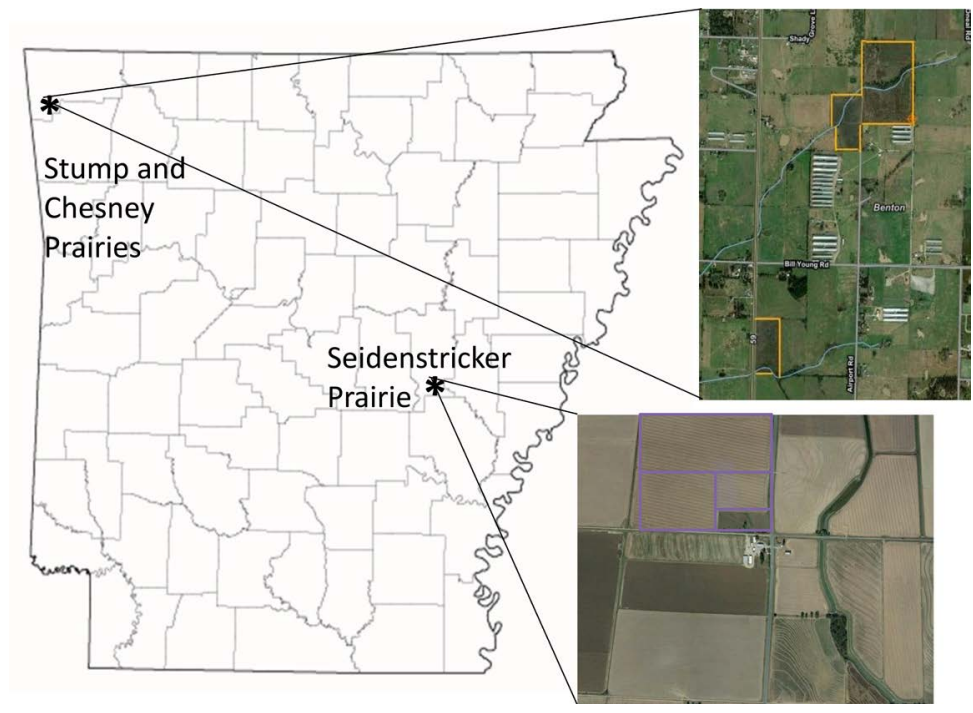

Figure 1. Geographic distribution of sites sampled in the Ozark Highlands in northwest Arkansas (Stump and Chesney Prairies) and in the Grand Prairie region of east-central Arkansas (Seidenstricker Prairie). Chesney Prairie is approximately $2 \mathrm{~km}$ north-northeast of Stump Prairie near Siloam Springs, Arkansas. At the Seidenstricker Prairie site, the native prairie is in the southeast corner of the property, with the three cultivated agricultural area surrounding the prairie to the west and north.

Oxyaquic Fragiudalfs [18]) is mapped throughout both prairie sites in the upland site positions with a udic soil moisture regime. The approximate elevation for the Stump and Chesney Prairies is $362 \mathrm{~m}$ above sea level [9].

Immediately adjacent to the remnant Stump and Chesney Prairies is agriculturally managed land of varying disturbance levels, thus contrasting landuses exist within the same soil map unit (Table 1; Figure 1). A managed, ungrazed grassland and a managed, grazed pasture are located immediately adjacent to the Stump Prairie [9]. The managed grassland is predominantly tall fescue, where aboveground vegetation had been removed by haying multiple times a year for the last 20 years prior to soil sampling for this study [9]. The managed pasture has been used for approximately the last 20 years to graze a small head of cattle multiple times per year prior to soil sampling for this study [9]. However, the managed pasture had never been cultivated, while the managed grassland has only been cultivated a few times in the last 20 years for replanting perennial grasses. At Chesney Prairie, which is approximately $2 \mathrm{~km}$ north and slightly east of the Stump Prairie, an area of previously cultivated agriculture exists within the Chesney Prairie Natural Area property boundary. The area was previously cropped to soybean (Glycine max), but the area has been taken out of cultivated agricultural production and had been managed as a prairie restoration for at least the last 15 years.

The Seidenstricker Prairie, which is presently an approximate 5-ha, fragmented tallgrass prairie remnant, is located in the Grand Prairie in Prairie County, Arkansas (Table 1; Figure 1). The prairie was once larger, but parcels of the prairie have been periodically converted to cultivated agriculture over the past 60 years. 
Presently, the Seidenstricker Prairie is surrounded by three cultivated agricultural fields that share similar soil mapping units to those that exist within the prairie. The three cultivated agricultural fields were converted from native prairie in 1957,1975 , and 1981, respectively, thus cultivated agriculture had been the consistent landuse for 44, 26, and 20 years, respectively, at the time of initial soil sampling for this study (Table 1). All three cultivated agricultural fields are presently managed in a rice (Oryza sativa)-soybean-wheat (Triticum aestivum) rotation. Consequently, due to the fragmentation of the once-larger native prairie area, the present native prairie area and the three cultivated agricultural sites represent a chronosequence with differing durations of soil disturbance (i.e. 0 , 20,26 , and 44 years) at the time of initial soil sampling for this study. Dewitt silt loam (fine, smectitic, thermic Typic Albaqualf [18]) is mapped throughout the prairie and adjacent cultivated agricultural areas, has alluvial parent material, and is poorly drained and slowly permeable [19]. The approximate elevation for the Seidenstricker Prairie is $65.2 \mathrm{~m}$ above sea level.

\subsection{Soil Sampling and Processing}

Initial soil samples were collected between early August 2001 and mid-April 2002 from the top $10 \mathrm{~cm}$ with a slide hammer and a $4.8-\mathrm{cm}$-diameter, stainless steel core chamber at five sampling points spaced $15-\mathrm{m}$ apart along a $60-\mathrm{m}$ line transect (i.e. the 0-, 15-, 30-, 45-, and 60-m marks) at all three prairie sites and their adjacent agriculturally managed/disturbed sites. Soil samples were collected again along the same original transect from the 0 - to $10-\mathrm{cm}$ soil depth at all sites between late October and early November 2016. The different sampling months were due to logistical constraints gaining access to each site and scheduling conflicts.

All soil samples were oven-dried at $70^{\circ} \mathrm{C}$ for at least 48 hours and weighed for bulk density determination. Soil was then crushed and sieved through a $2-\mathrm{mm}$ mesh screen for soil chemical analyses. Sub-samples were extracted in a 1:10 soil mass:extractant-solution-volume ratio [20] and analyzed by inductively coupled, argon-plasma spectrometry (Spectro Arcos ICP, Spectro Analytical Instruments, Inc., Kleve, Germany) to determine extractable soil nutrients (i.e. $\mathrm{P}, \mathrm{K}, \mathrm{Ca}, \mathrm{Mg}$, $\mathrm{S}, \mathrm{Na}, \mathrm{Fe}, \mathrm{Mn}, \mathrm{Zn}$, and $\mathrm{Cu}$ ).

Measured concentrations ( $\mathrm{mg} \cdot \mathrm{kg}^{-1}$ ) were converted to contents ( $\mathrm{kg}$ or Mg.ha ${ }^{-1}$ ) using the measured bulk density and $10-\mathrm{cm}$ sample depth. Soil bulk density data from the initial soil sampling (i.e. 2001/2002) were reported in Brye and West [9] for the Stump and Chesney Prairies and in Brye [21] for the Seidenstricker Prairie, while bulk density data from the 2016 sampling were reported in McKee et al. [5] for all sites. Soil property changes over time were calculated by transect point by subtracting the 2001/2002-measured results from the 2016-measured results and dividing by the fractional time to the nearest day, such that positive changes represented an increase, while a negative change represented a decrease over time. Soil chemical property results from the initial soil sampling (i.e. 
2001/2002) at the Stump and Chesney Prairies were reported in Brye and West [9], while initial soil properties for the Seidenstricker Prairie were reported in Brye [21].

\subsection{Statistical Analyses}

Based on similar procedures used recently by McKee et al. [5], a two-factor analysis of variance (ANOVA) was performed using the PROC GLIMMIX procedure in SAS (version 9.4, SAS Institute, Inc., Cary, NC) to evaluate the effect of region (i.e. Ozark Highlands and Grand Prairie), landuse (i.e. native prairie and managed agriculture), and their interaction on the change in extractable soil nutrient contents in the top $10 \mathrm{~cm}$ over time (i.e. the approximate 15-year period between soil samplings). Significance was judged at $P<0.05$ for all statistical analyses. When appropriate, least significant difference (LSD) was used to separate means at the 0.05 level.

\section{Results and Discussion}

After 15 years of continued prairie function or agricultural land management, nearly all changes in soil chemical properties measured in the top $10 \mathrm{~cm}$ over time were affected by region, landuse, or both (Table 2). Changes in extractable soil $\mathrm{Ca}, \mathrm{Mg}$, and $\mathrm{Zn}$ over time varied between landuses within regions $(P<0.01)$, while changes in extractable soil $\mathrm{S}, \mathrm{Na}$, and $\mathrm{Mn}$ over time differed between regions $(P<0.01)$, and changes in extractable soil $\mathrm{Fe}$ and $\mathrm{Mn}$ over time differed between landuses $(P<0.02$; Table 2$)$.

Table 2. Analysis of variance summary of the effects of region (i.e. Ozark Highlands and Grand Prairie), landuse (i.e. native prairie and managed agricultures), and their interaction on the change in selected soil chemical [i.e. Mehlich-3 extractable soil phosphorus $(\mathrm{P})$, potassium $(\mathrm{K})$, calcium $(\mathrm{Ca})$, magnesium $(\mathrm{Mg})$, sulfur $(\mathrm{S})$, sodium $(\mathrm{Na})$, iron $(\mathrm{Fe})$, manganese $(\mathrm{Mn})$, zinc $(\mathrm{Zn})$, and copper $(\mathrm{Cu})$ contents] properties in the top $10 \mathrm{~cm}$ over a 15-year period in Arkansas.

\begin{tabular}{cccc}
\hline Soil Property & Region & Landuse & Region $\times$ Landuse \\
\cline { 2 - 4 } $\mathrm{P}$ & 0.21 & $\boldsymbol{P}$ & \\
$\mathrm{K}$ & 0.49 & 0.11 & 0.29 \\
$\mathrm{Ca}$ & 0.01 & 0.04 & 0.40 \\
$\mathrm{Mg}$ & $<0.01$ & 0.80 & $<0.01$ \\
$\mathrm{~S}$ & 0.01 & 0.85 & $<0.01$ \\
$\mathrm{Na}$ & $<0.01$ & 0.27 & 0.80 \\
$\mathrm{Fe}$ & 0.63 & 0.02 & 0.89 \\
$\mathrm{Mn}$ & $<0.01$ & 0.01 & 0.76 \\
$\mathrm{Zn}$ & $<0.01$ & 0.07 & 0.14 \\
$\mathrm{Cu}$ & 0.89 & 0.75 & $<0.01$ \\
& & & 0.87
\end{tabular}


Extractable soil $\mathrm{Ca}$ increased over time $(P<0.05)$ under cultivated agriculture in the Grand Prairie and under native prairie in the Ozark Highlands, while extractable soil Ca did not change over time under managed agriculture in the Ozark Highlands and under native prairie in the Grand Prairie (Figure 2). The change in extractable soil $\mathrm{Ca}$ was more than four times greater under cultivated agriculture in the Grand Prairie (39.7 kg.ha ${ }^{-1} \cdot \mathrm{yr}^{-1}$ ) than under native prairie in the Ozark Highlands $\left(14.0 \mathrm{~kg} \cdot \mathrm{ha}^{-1} \cdot \mathrm{yr}^{-1}\right)$ and under managed agriculture in the Ozark Highlands and native prairie in the Grand Prairie, which did not differ (Figure 2). The increase in extractable soil $\mathrm{Ca}$ under managed agriculture in the Grand Prairie could be attributed to the practice of periodic liming to maintain at least a minimum soil $\mathrm{pH}$ for optimum nutrient availability. Calcium enrichment over time under agricultural landuse in the Grand Prairie may have also occurred as a result of $\mathrm{P}$ fertilization with common fertilizer-P sources that contain $\mathrm{Ca}$ as a charge-balancing carrier cation. Irrigation water in the Grand Prairie is also bicarbonate rich, which could have also contributed to the increase in extractable soil $\mathrm{Ca}$ under cultivated agriculture in the Grand Prairie. Brye and Pirani [8] also reported that extractable soil $\mathrm{Ca}$ was generally greater under managed agricultural landuse compared to native prairie in the Grand Prairie of east-central Arkansas.

Similar to $\mathrm{Ca}$, extractable soil $\mathrm{Mg}$ increased over time $(P<0.05)$ under cultivated agriculture in the Grand Prairie, while extractable soil Mg did not change over time under managed agriculture or native prairie in the Ozark Highlands and under native prairie in the Grand Prairie (Figure 2). The change in extractable soil $\mathrm{Mg}$ was more than two times greater under cultivated agriculture in the Grand Prairie $\left(5.9 \mathrm{~kg} \cdot \mathrm{ha}^{-1} \cdot \mathrm{yr}^{-1}\right)$ than under native prairie in the Grand Prairie

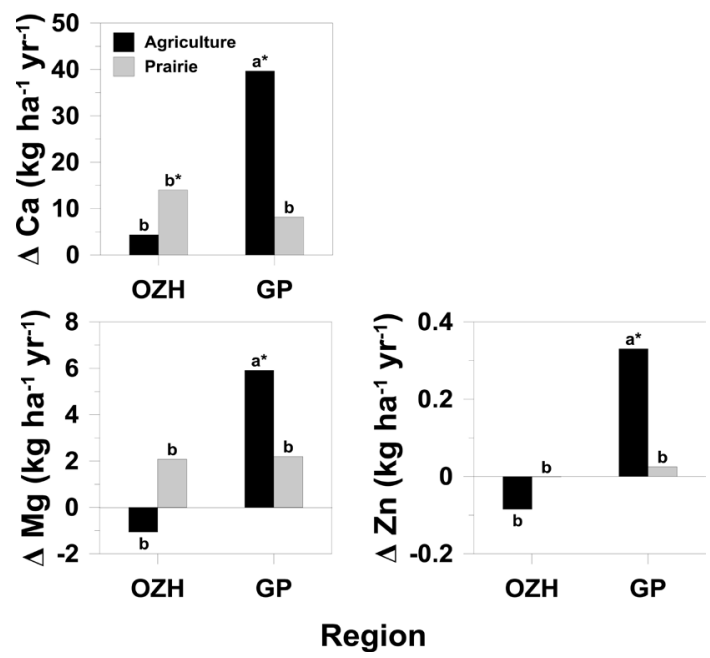

Figure 2. Landuse effects by physiographic region on calcium (Ca), magnesium $(\mathrm{Mg})$, and zinc $(\mathrm{Zn})$ in the top $10 \mathrm{~cm}$ of soil from samples taken in 2016 under cultivated agriculture (AG) or undisturbed prairie (PR) landuses in the Ozark Highlands $(\mathrm{OZH})$ of northwest Arkansas and the Grand Prairie (GP) of east-central Arkansas. Different letters associated with mean values on a panel are different at $P<0.05$. Asterisks indicate a significant $(P<0.05)$ change over time. 
and either landuse in the Ozark Highlands, which did not differ (Figure 2). Brye and Pirani [8] also reported that extractable soil $\mathrm{Mg}$ was generally greater under managed agriculture compared to native prairie in the Grand Prairie. In addition to adding $\mathrm{Ca}$, agricultural lime materials often contain $\mathrm{Mg}$ as well if dolomite is used.

Similar to $\mathrm{Ca}$ and $\mathrm{Mg}$, extractable soil $\mathrm{Zn}$ increased over time $(P<0.05)$ under cultivated agriculture in the Grand Prairie, while extractable soil $\mathrm{Zn}$ did not change over time under managed agriculture or native prairie in the Ozark Highlands and under native prairie in the Grand Prairie (Figure 2). The change in extractable soil $\mathrm{Zn}$ was about 10 times greater under cultivated agriculture in the Grand Prairie $\left(0.3 \mathrm{~kg} \cdot \mathrm{ha}^{-1} \cdot \mathrm{yr}^{-1}\right)$ than under native prairie in the Grand Prairie and either landuse in the Ozark Highlands, which did not differ (Figure 2). Zinc is an essential plant micronutrient, thus $\mathrm{Zn}$ is periodically added while fertilizing row crops for optimal productivity.

Averaged across landuse, extractable soil $S$ increased over time $(P<0.05)$ in the Ozark Highlands, but was unchanged over time in the Grand Prairie (Table 3). The change in extractable soil S over time was nine times greater in the Ozark Highlands than in the Grand Prairie (Table 3). As a natural component of SOM, soil S likely increased as a result of the numeric, though non-significant, increase in SOM content in the Ozark Highlands, while SOM content significantly decreased in the Grand Prairie as reported by McKee et al. [5] over the same 15-yr time period and same treatments as in the current study. In contrast to $S$, averaged across landuse, extractable soil $\mathrm{Na}$ and $\mathrm{Mn}$ increased over time $(P<0.05)$ in the Grand Prairie, but were unchanged over time in the Ozark Highlands (Table 3). The change in extractable soil $\mathrm{Na}$ and $\mathrm{Mn}$ over time were 6.4 and 10 times greater, respectively, in the Grand Prairie than in the Ozark Highlands (Table 3). Much of the Grand Prairie region of east-central Arkansas is characterized by soils in aquic soil moisture regimes (Table 1) and with relatively shallow water tables. Considering that $\mathrm{Mn}$ is prone to oxidation-reduction reactions as a result of water-logging and the development of anaerobic/reducing conditions, the periodic water-table fluctuations during wet seasons are likely responsible for the dissolution and re-precipitation of Mn near the soil surface in the Grand Prairie. In contrast, water tables in the Ozark Highlands tend to be deeper than in the Grand Prairie, which characterizes the udic soils sampled in the

Table 3. Summary of mean soil property changes within physiographic region (i.e. Ozark Highlands and Grand Prairie), averaged across landuse, over a 15-year period for extractable soil sulfur $(\mathrm{S})$, sodium $(\mathrm{Na})$, and manganese $(\mathrm{Mn})$ contents in the top $10 \mathrm{~cm}$.

\begin{tabular}{ccc}
\hline Soil Property & Ozark Highlands & Grand Prairie \\
\hline $\mathrm{S}\left(\mathrm{kg} \cdot \mathrm{ha}^{-1} \cdot \mathrm{yr}^{-1}\right)$ & $0.9 \mathrm{a}^{*}$ & $0.1 \mathrm{~b}$ \\
$\mathrm{Na}\left(\mathrm{kg}^{\mathrm{ha}} \mathrm{ha}^{-1} \cdot \mathrm{yr}^{-1}\right)$ & $0.5 \mathrm{~b}$ & $3.2 \mathrm{a}^{*}$ \\
$\mathrm{Mn}\left(\mathrm{kg} \cdot \mathrm{ha}^{-1} \cdot \mathrm{yr}^{-1}\right)$ & $0.6 \mathrm{~b}$ & $6.0 \mathrm{a}^{*}$ \\
\hline
\end{tabular}

${ }^{\dagger}$ Different letters in a row indicate a significant difference $(P<0.05) .{ }^{*}$ Asterisks indicate a significant $(P<$ $0.05)$ change over time. 
Ozark Highlands in this study (Table 1). Though soils in the Grand Prairie are mostly non-saline and non-sodic, the groundwater used extensively for row-crop irrigation contains $\mathrm{Na}$ that enriches the soil upon evaporation.

Averaged across regions, extractable soil Fe increased over time $\left(3.8 \mathrm{~kg} \cdot \mathrm{ha}^{-1} \cdot \mathrm{yr}^{-1}\right.$; $P<0.05$; Table 2) under agricultural landuse, but remained unchanged over time under native prairie landuse. The periodic soil disturbances experienced by the agricultural landuses, even the essentially non-cultivated agriculture in the Ozark Highlands, likely promoted greater fluctuations in soil moisture and temperature to promote further weathering, thus releasing more Fe than in the comparatively much less disturbed native prairie landuse. Similar to $\mathrm{Fe}$, averaged across regions, extractable soil $\mathrm{Mn}$ also increased over time $\left(1.9 \mathrm{~kg} \cdot \mathrm{ha}^{-1} \cdot \mathrm{yr}^{-1} ; P<\right.$ 0.05 ; Table 2) under agricultural landuse. However, in contrast to Fe, extractable soil Mn also increased over time $\left(4.7 \mathrm{~kg} \cdot \mathrm{ha}^{-1} \cdot \mathrm{yr}^{-1} ; P<0.05\right.$; Table 2$)$ under native prairie landuse, where the increase over time was greater under native prairie than under agricultural landuse. Similar to in aquic soil moisture conditions, Mn can, and often does, accumulate as Fe-Mn masses and/or concretions in even well-drained soils during wet seasons, thus it is not surprising that soil Mn increased over time in both landuses. In addition, the generally more well-drained soil conditions in native prairies from the generally stronger soil aggregation and wider aggregate-size distribution than in agricultural soils may differentially promote greater $\mathrm{Mn}$ accumulation as precipitated $\mathrm{Fe}-\mathrm{Mn}$ masses and/or concretions.

In contrast to all other measured extractable soil nutrients, changes in extractable soil $\mathrm{P}, \mathrm{K}$, and $\mathrm{Cu}$ over time were unaffected by region or landuse (Table 2). However, extractable soil $\mathrm{P}, \mathrm{K}$, and $\mathrm{Cu}$ each had region-landuse combinations that changed over time, despite the changes being unaffected by region or landuse. Extractable soil $\mathrm{P}\left(-1.6 \mathrm{~kg} \cdot \mathrm{ha}^{-1} \cdot \mathrm{yr}^{-1}\right)$ and $\mathrm{Cu}\left(-0.07 \mathrm{~kg} \cdot \mathrm{ha}^{-1} \cdot \mathrm{yr}^{-1}\right)$ decreased over time $(P<0.05)$ under managed agricultural landuse in the Ozark Highlands, but did not change over time under the other three region-landuse combinations. In contrast to soil $\mathrm{P}$ and $\mathrm{Cu}$, extractable soil $\mathrm{K}$ decreased over time $\left(-1.8 \mathrm{~kg} \cdot \mathrm{ha}^{-1} \cdot \mathrm{yr}^{-1} ; P<0.05\right)$ under cultivated agriculture in the Grand Prairie, but did not change over time under the other three region-landuse combinations. Though $\mathrm{P}$ and $\mathrm{K}$ are often applied fertilizer nutrients to agroecosystems, both nutrients tend to be applied to meet crop needs for a given year and not often applied in excess of crop needs to build up $\mathrm{P}$ or $\mathrm{K}$ in the soil for the future. Alternatively, SOM decomposition would be the natural source of soil nutrients in the absence of fertilization, such as in a native prairie, or when fertilization rates only meet crop nutrient requirements for a given year, such as under agricultural management. However, over the same 15 -yr time period and same treatments as in the current study, McKee et al. [5] reported that, averaged across native prairie and agricultural landuses, $\mathrm{SOM}$ contents in the top $10 \mathrm{~cm}$ decreased over time, which likely at least partially explains the decline in soil $\mathrm{P}, \mathrm{K}$, and $\mathrm{Cu}$ over time.

McKee et al. [5] also reported that soil bulk density in the top $10 \mathrm{~cm}$ did not 
change over time, nor did changes in soil bulk density differ between landuses or regions. Consequently, no changes in any soil nutrient measured in this study over time could have been a simple result of bulk density changes, but rather any change over time (i.e. increase or decrease) was the result of a substantial change in nutrient concentration over time. In contrast to soil bulk density, McKee et al. [5] reported that soil $\mathrm{pH}$ changed over time in the top $10 \mathrm{~cm}$ differentially among treatment combinations, where soil $\mathrm{pH}$ increased over time under cultivated agriculture in the Grand Prairie and decreased over time under managed agriculture in the Ozark Highlands, while soil $\mathrm{pH}$ did not change over time under native prairie in either region. Changes in soil $\mathrm{pH}$ among region-landuse combinations likely at least partially contributed to changes in soil nutrients over time and among region-landuse combinations measured in this study.

Though the objective of this long-term field study was not to specifically identify actual mechanisms of soil nutrient change over time, decreases in soil nutrients over time may have been the result of leaching below the top $10 \mathrm{~cm}$ of soil sampled or due to off-site removal from agricultural harvesting or periodic prescribed burning in the native prairies. Of the soil nutrients measured in this study, none would have been expected to have large volatilization losses. In contrast, increases in soil nutrients over time may have been the result of agricultural fertilization, natural SOM mineralization, near-surface water-table fluctuations, or a combination of these processes.

\section{Conclusions}

Near-surface extractable soil nutrients (i.e. P, K, Ca, Mg, S, Na, Fe, Mn, Zn, and $\mathrm{Cu}$ ) were measured in over the 15-yr period in the Ozark Highlands and the Grand Prairie regions of Arkansas under native prairie and managed agriculture landuses. Extractable soil $\mathrm{Ca}, \mathrm{Mg}$, and $\mathrm{Zn}$ changes over time differed between landuses within regions. Extractable soil $\mathrm{S}, \mathrm{Na}$, and $\mathrm{Mn}$ changes over time differed between regions, while extractable soil $\mathrm{Fe}$ and $\mathrm{Mn}$ changes over time differed between landuses. Extractable soil $\mathrm{P}, \mathrm{K}$, and $\mathrm{Cu}$ in at least one of four region-landuse combinations changed over time, but changes over time were unaffected by region or landuse.

Results from this long-term study demonstrate that 15 years is likely ample time to assess actual temporal changes in near-surface soil properties and to minimize the potential for mistakenly concluding that temporal changes in soil properties are attributed to reasons other than simple inter-annual variability. Results from this field study also clearly demonstrate how differences in landuse and regional soil characteristics can affect near-surface soil nutrient contents, which should be taken into consideration when implementing conservation and/or ecosystem restoration activities.

\section{Acknowledgements}

The Seidenstricker family in east-central Arkansas and Joe Woolbright in north- 
west Arkansas are gratefully acknowledged for their assistance providing access to the prairie and agricultural sites sampled in this study.

\section{Conflicts of Interest}

The authors declare no conflicts of interest regarding the publication of this paper.

\section{References}

[1] Samson, F. and Knopf, F. (1994) Prairie Conservation in North America. Bioscience, 44, 418-421. https://doi.org/10.2307/1312365

[2] Blanco, H. and Rattan, L. (2008) Principles of Soil Conservation and Management. Springer Science + Business Media, Washington DC.

[3] Steinauer, E.M. and Collins, S.L. (1996) Prairie Ecology-The Tallgrass Prairie. In: Samson, F. and Knopf, F., Eds., Prairie Conservation: Preserving North America's Most Endangered Ecosystem, Island Press, Washington DC, 39-52.

[4] Six, J., Bossuyt, H., Degryze, S. and Denef, K. (2004) A History of Research on the Link between (Micro)aggregates, Soil Biota, and Soil Organic Matter Dynamics. Soil and Tillage Research, 79, 7-31. https://doi.org/10.1016/j.still.2004.03.008

[5] McKee, M., Brye, K.R. and Wood, L. (2019) Landuse and Physiographic Region Effects on Soil Carbon and Nitrogen Sequestration in Arkansas. In: Frazão, L.A., Ed., $\mathrm{CO}_{2}$ Sequestration, IntechOpen, London, 1-21. https://doi.org/10.5772/intechopen.83783

[6] Brye, K.R. and Moreno, L. (2006) Vegetation Removal Effects on Soil Quality in a Native Tallgrass Prairie Fragment in East Central Arkansas. Natural Areas Journal, 26, 94-100. https://doi.org/10.3375/0885-8608(2006)26[94:VREOSQ]2.0.CO;2

[7] Brye, K.R., West, C.P. and Gbur, E.E. (2004) Soil Quality Differences under Native Tallgrass Prairie across a Climosequence in Arkansas. The American Midland Naturalist, 152, 214-230. https://doi.org/10.1674/0003-0031(2004)152[0214:SQDUNT]2.0.CO;2

[8] Brye, K.R. and Pirani, A.L. (2005) Native Soil Quality and the Effects of Tillage in the Grand Prairie Region of Eastern Arkansas. The American Midland Naturalist, 154, 28-41. https://doi.org/10.1674/0003-0031(2005)154[0028:NSQATE]2.0.CO;2

[9] Brye, K.R. and West, C.P. (2005) Grassland Management Effects in Soil Surface Properties in the Ozark Highlands. Soil Science, 170, 63-73.

https://doi.org/10.1097/00010694-200501000-00008

[10] United States Department of Agriculture, Soil Conservation Service (2006) Land Resource Regions and Major Land Resource Areas of the United States, the Caribbean, and the Pacific Basin. U.S. Department of Agriculture Handbook 296, Washington DC.

[11] Brye, K.R. and Gbur, E.E. (2011) Near-Surface Soil Property Changes over Time as Effected by Grassland Management in the Ozark Highlands. Soil Science, 176, 129-135. https://doi.org/10.1097/SS.0b013e31820ca9a8

[12] Natural Resource Conservation Service (NRCS) (2020) Web Soil Survey. http://websoilsurvey.nrcs.usda.gov

[13] Arkansas Natural Heritage Commission (ANHC) (2009) System of Natural Areas: Natural Areas. http://naturalheritage.com/NaturalAreas/Natural-Areas-1

[14] National Centers for Environmental Information (NCEI) (2010) Data Tools: 1981-2010 
Normals. National Climatic Data Center.

https://www.ncdc.noaa.gov/cdo-web/datatools/normals

[15] Holiman, B., Woolbright, J. and James, D. (2013) Increasing Grassland Block Size and Restoring Ozark Prairie and Woodlands. Arkansas State Wildlife Grant Pre-Proposal. https://www.wildlifearkansas.com/proposals/2013PreProposals/Increasing\%20Gras sland\%20Block\%20Size\%20and\%20Restoring\%20Ozark\%20Prairie\%20and\%20Wo odlands.pdf

[16] Neal, J. and Mlodnow, M. (2012) Chesney Prairie Natural Area, Siloam Springs. http://nwarkaudubon.org/Places\%20to\%20Bird\%20PDFs/BIRDING-CHESNEY-PR AIRIE-NATURAL-AREA.pdf

[17] Durre, T., Brye, K.R., Wood, L. and Gbur, E.E. (2019) Soil Moisture Regime and Mound Position Effects on Soil Properties in a Native Tallgrass Prairie in Northwest Arkansas, USA. Geoderma, 352, 49-60. https://doi.org/10.1016/j.geoderma.2019.05.045

[18] United States Department of Agriculture, Natural Resources Conservation Service (2000) Official Soil Description: Jay Soil Series. https://soilseries.sc.egov.usda.gov/OSD_Docs/J/JAY.html

[19] United States Department of Agriculture, Natural Resources Conservation Service (2014) Official Soil Description: Dewitt Soil Series. https://soilseries.sc.egov.usda.gov/OSD_Docs/D/DEWITT.html

[20] Tucker, M.R. (1992) Determination of Phosphorus by Mehlich 3 Extraction. In: Donohue, S.J., Ed., Soil and Media Diagnostic Procedures for the Southern Region of the United States, Virginia Agricultural Experiment Station Series Bulletin 374, Blacksburg, 6-8.

[21] Brye, K.R. (2006) Soil Physiochemical Changes Following 12 Years of Annual Burning in a Humid-Subtropical Tallgrass Prairie: A Hypothesis. Acta Oecologica, 30, 407-413. https://doi.org/10.1016/j.actao.2006.06.001 